\title{
Political Zionism and Fiction: A Study of John Updike's Terrorist
}

\author{
Maryam Salehnia \\ English Department, Faculty of Foreign Languages, University of Isfahan, Iran \\ Email: m.salehnia@yahoo.com
}

\begin{abstract}
Since its creation in 1948, Israel has more visibly touched upon different discourses, such as political, cultural and religious, to legitimize its existence in Palestine, a land that had nothing to do with Holocaust and Nazi's violence against European Jews. Regarding the deep political influence and power of Israel over the United States, the present writer would attempt to trace such influence in recently-written American fictions which deal with the newly-shaped genre, 'literary terrorism', especially John Updike's Terrorist (2006). Having witnessed the terrorist attacks of September 11, Updike, one of the most committed American writers, portrayed an Arab-American teenage boy, Ahmad, whose extremist justifications would have turned him into an anti-hero, if Jack Levy, the Jewish protagonist of the novel, had not changed his mind at the end of the novel. Here, Updike focuses on the Orientalist and Neo-Orientalist binary opposition of 'the Self'/ 'the Other', represented by Jack and Ahmad, in order to demonstrate and justify the claimed superiority of the 'the West' (or 'Israel' here) over 'the Orient'.
\end{abstract}

\section{Index Terms-Neo-Orientalism, John Updike, political zionism, literary terrorism}

Although the murmurs of constituting a nation for the Jews were heard in the late $19^{\text {th }}$ century, it was World War I which intensified the debates over this issue. When World War I broke out and the violence over Jews increased in Europe, a few Jews claimed that they deserved the right to come back to what they considered to be their homeland. As Goldschmidt (1971) notes, "The rise to power of Hitler and his Nazi party in Germany put the Jews in that country in dire peril and many Jews tried to get out of the country" (p. 249). Since European countries were unable to offer them enough job opportunities, the only place which was left for them was the land of Palestine (Goldschmidt, 1971). It was at this time that political Zionism which was the belief that "the Jews should form and maintain a state for themselves" in their ancestral land was created (Ibid, p. 271). Consequently, the number of the Jew immigrants increased until they constituted a large part of the Arab population of Palestine. It was in 1948, that "the Jewish Agency Executive Committee formally declared that those parts of Palestine under Jewish control were now the independent state of Israel" (Ibid, p. 289).

Actually, heading to Palestine in order to live a peaceful life and escape racism and anti-Semitism was not motivated only by necessity and the suffering the Jews had undergone in Europe, but by "the serene assurance that they as Jews and Europeans were superior to the people whose land they proposed to 'acquire and appropriate'. Indeed they felt themselves superior to all the peoples of the Orient and they stated their superiority quite clearly" (Jansen, 1071, p. 149). This sense of superiority was inspired again by the old conflict between the West and Islam which showed itself off since the Crusades and especially in the middle of nineteenth century when "a branch of evangelical theology known as 'dispensationalism"" emerged and developed the idea of "Muslims as the inevitable enemy of God's plan to restore the Jews to their ancestral home in the holy land" (Kidd, 2010, p. 255-6).

As Mamdani claims in The Jew, The Arab: A History of the Enemy, colonization has two stages. He believes that, "Before you can try and eliminate an enemy, you must first define that enemy" (Anidjar, 2003, p. xvii). This belief, generally, is the basis of colonial powers policies because it legitimizes and as a result, necessitates the colonization of a country and people that are represented as uncivilized. Edward Said in "Zionism from the Standpoint of Its Victims" (1997), also, explains the process of Zionist colonization as such:

in its conscious and declared ideas about Palestine, Zionism attempted first to minimize, then to eliminate, then, all else failing, finally to subjugate the natives as a way of guaranteeing that Israel would not be simply the state of its citizens (which included Arabs of course) but the state of the whole Jewish people, having a kind of sovereignty over land and peoples that no other state possessed or possesses (p. 32).

As Said asserts in the same article, "The native Arabs had to be seen as an irremediable opposite, something like a combination of savage and superhuman, at any rate a being with whom it is impossible to come to terms" (p. 34). Also, in Orientalism (1978), he notes that if the Arab is mentioned in Orientalist texts, he is regarded only as:

The disruptor of Israel's and the West's existence, or in another view of the same thing, as a surmountable obstacle to Israel's creation in 1948. In so far as this Arab has any history, it is part of the history given him (or taken from him: the difference is slight) by the Orientalist tradition, and later the Zionist tradition (p. 286).

According to the supporters of imperialism, "it has distinct 'moral', economic and psychological characteristics, and Israel today displays them all. The 'moral' characteristic is that the imperialist must believe that he has a duty, an obligation, a mission to rule 'the lesser tribes without the law' for their own good" (Jansen, 1971, p. 329). Zionists 
claim that they have been beneficial not only in bringing law and order to the barbarian inhabitants of Palestine, but also in making habitable the land which was more like a dessert before the arrival of Zionists. Further, they believe that Zionism will restore 'a lost fatherland', and in so doing mediate between the various civilizations; that present day Palestine was in need of cultivation, civilization, reconstitution; that Zionism would finally bring Enlightenment and progress where at present there was neither (Said, 1997). As such, Zionism portrayed itself as an imperial power "bringing civilization to a barbaric and/or empty locale" and then as a "movement bringing Western democracy to the East" (Ibid, p. 17).

After defining Palestinians as uncivilized natives who even do not know how to cultivate their own lands and people over which an imperial power ought to be dominant, Zionists started the second stage of colonization, the elimination of Palestinians and their history. As Edward Said (1997) states, "The Zionists set out systematically either to reduce the Palestinians to a nonexistent population or to strip down those who remained to the status of a silent coolie class" ( $p$. 18). Then, he continues, "The intention to create a Jewish National Home is to cause the disappearance or subordination of the Arab population, culture and language" (p. 31). Therefore, Zionism, as a newly-shaped power which is endowed with the support of superpowers like the United States, has "effaced the Palestinians, his or her history, his or her actuality" in the same way that Western imperialists had effaced the actuality and history of their colonies before (p. 18)

In Orientalism (1978), Said also believes that the inferiority that the West attributes to the East simultaneously serves to construct the West's superiority. Identity, for Said, whether of Orient or Occident, is a construction which involves the construction of opposites and 'others' whose actuality is always subject to the continuous interpretation and reinterpretation of their differences from 'us'. The West always functions as the 'center' and the East is a marginal 'other' that simply through its existence confirms the West's centrality and superiority (Bertens, 2001). Zionism, as the best evidence of this fact, took the advantage of defining, legitimizing and consolidating its political basis and superiority by depicting itself as a messenger of Western culture and civilization. As Herzl, one of Zionist leaders, argued,

It is more and more to the interest of the civilized nations and of civilization in general that a cultural station be established on the shortest road to Asia.Palestine in this station and we Jews are the bearers of culture who are ready to give our property and our lives to bring about its creation (qtd. in Jansen, 1971, p. 83).

The legitimization process was programmed not only to define the Arabs through age-old Oriental clichés, but also in accordance with Neo-Orientalist discourse to represent them as natural-born terrorists. Logically speaking, any action toward the usurpation of a country inspires responses and reactions on the part of the natives and settlers of the target country and consequently, every attacker ought to expect counterattacks. Thus, even Zionist historians have empirically shown the idea of Jewish colonizers in Palestine always met with quite unmistakable native resistance, not because the natives thought that Jews were evil but because no natives take kindly to having their territory settled by foreigners (Said, 1997). But what have been pictured and called in Zionism-supporting media and writings were far beyond the truth of native resistance and defense against the usurpers. The almost total absence of any source of knowledge considering the history, life and resistance of Palestinian settlers accompanied by the incredible investment of Zionism and its allies in disseminating malicious political clichés of Palestinian natives in both high and low cultural areas of the West, paved the way for Israel to legitimize its racist crimes in Palestine.

Another strategy, which suppresses both Arabs' and Western intellectuals' publicly declared criticisms leveled at Israeli's racist and genocidal policies, is to call them anti-Semitism. According to this policy, Palestinians "are charged with anti-Semitism if they complain about the destruction of their villages; the ethnic cleansing of their cities; the loss of their country and right to citizenship; house demolitions; discrimination against Muslims and Christian Palestinians; the program of targeted assassinations; the well documented cases of torture" (Corrigan, 2009, p. 155). The individuals, activists or politicians in the United States and Europe who criticize human-rights problems in Israel or question the basic political ideology of Zionism are accused of anti-Semitism and racism as well. Therefore, from 1948 onward, charging those against Zionism movement policies with anti-Semitism has been perceived as an effective political weapon which, as George Soros notices, has been able to "silence the political debate on Israeli's policies toward the Palestinians" (Ibid, p. 148) and it could not be done without boundless Western and especially American support of Israel.

Regarding the nature of Zionist movement as moral and liberating, America coordinates with the Jewish state in war against terrorism since September 11, 2001. Although this coordination returns back to the years before the attacks of September 11, 2001, one could claim that it has increased in the years following that date. What Americans did in the recent years was to share the horror of the terrorist attacks in America's soil with Israelis who, as propaganda emphasized, were the victims of Palestinian terrorist attacks. They regarded Arab resistance done mostly through suicidal bombings as terrorist attacks on Israel and intentionally ignored the conditions that had led to such attacks. Thus, by calling all resistance terrorism as well as spiteful and pre-programmed portraying of what was going on in the Occupied Territories, Zionism did her best to turn the tide and reverse the public criticism to public approval; the approval which would never be gained if terrorist attacks of September 11 had not occurred. Therefore, one could conclude that what happened in that black Tuesday was an appropriate opportunity for both Israel and the United States through which they got the chance to justify their colonial policies and political interference in internal affairs of the Middle Eastern countries. 
As it is obvious, the United States' and Israel's relationship is not confined to their alliance for the so-called war against terrorism or the attempt to 'civilize' the Arabs. During his visit in May 2008 to participate in the 60-year anniversary celebration of Israel, the United States president George W. Bush addressed the Israeli Knesset: "the alliance between our governments is unbreakable, yet the source of friendship runs deeper than any treaty" (qtd. in Qumsiyeb, 2008, p. 181). Indeed, Israel has proved to be an issue of special attention in U.S. policy in the Middle East. Many scholars discuss that their relationship has turned out to be associated with unusual levels of mutual dependency and support though it has experienced some frictions. Definitely, the United States has always had the role of a supporter and Israel has been supposed to act as a defense partner in this relationship. "U.S. and Israeli officials covertly coordinated intelligence operations and Israel's development of nuclear weaponry" in order to consolidate the pillars of Israel state in Palestine and enable it to play the role of the defender of the US interests in the Middle East (Schulzinger, 2006, p. 379). But as American politicians confess, the influence and pressure of pro-Israel lobby inside the United States have reached a point that makes America defenseless against Israel's demands. Thus, the relationship between Israel and U.S. seems to be an unequal one according to which the influence and authority of pro-Israel lobby inside the U.S., due to their secret security information about the U.S. Security Services, has led to "suppressing books, restricting free speech, and unduly pressuring government officials" (Ibid).

Since its birth, political Zionism has resorted to different discourses to legitimize its colonial tendencies. Literature, regarded as an influential discourse due to its concern with politics and history, has been no exception to this. The impact of political Zionism in recently-written American fictions which deal with the newly-shaped genre, 'literary terrorism' has become obvious from one story to another, from one novel to the other. Many writers, whether Jewish or not, have dealt with Jews as major or minor characters in their works. Although the presence of Jewish characters in literature could not be limited to the twenty-first century literature, one could definitely claim that this presence has been enhanced and even changed during the recent years under the boundless authority of Zionists over different fields of American culture, such as literature.

Updike's Terrorist is an example of the writer's attempt at participating in the literary terrorism which was practiced as the direct result of the terror attacks of September 11. Though known as the 'bard of the middle class mundane', Updike moved beyond his consistency in dealing with daily lives events of his characters to a new American worldview in order to conform himself with the transforming world; a world which had headed for division, the division between the West and the East.

Since the novel has been inspired directly by the American hatred of Islamic fundamentalists, one could consider it as a political-religious one whose political aspect could be associated with the Arab-Israeli conflicts. Ahmad, the hero of the story, influenced by his Muslim teacher, Shaikh Rashid, and in spite of Jack Levy's warning, the Jewish character of the novel, decides to join a furnishing company as a truck driver, later revealed to be associated with Islamic fundamentalism. Though Ahmad prepares himself to do the terrorist operation assigned to him to be fulfilled, Jack succeeds in stopping him by reminding him that God's will is on creation and life rather than destruction, the fact that Ahmad as an extremist Muslim had ignored. Thus, by dissuading Ahmad from exploding the bomb, Levy robs him of his previous title as the hero of the story and introduces himself as the lovable hero of the novel who as a matter of fact, is a Jewish one; A hero whose primary concern has been to warn Ahmad against his extremist beliefs and guide him to the right decision; a hero whose very presence as a Jew and his similarities to Arab-American Ahmad and differences from him, both legitimize the colonial motives of political Zionism and question the motives of fundamentalists for committing terrorist crimes.

The first descriptions of Jack Levy introduce him as a perfect father and husband who has done whatever he has been supposed to do during his lifetime and is now absolutely ready to embrace his death:

...all that is left on Earth for his body is to ready itself for death. He has done his courting and mating; he has fathered a child; he has worked to feed that child, little sensitive Mark with his shy cloudy eyes and slippery lower lip, and to furnish him with all the tawdry junk the culture of the time insisted he possess, to blend in with his peers. Now Jack Levy's sole remaining task is to die and thus contribute a little space, a little breathing room, to this overburdened planet (Terrorist, p. 20).

But as the novel goes on, Levy turns out to be not the hero one would imagine due to the above descriptions, but a 'drag', as he names himself, who has lost all his hopeful connections to the world. He seems to be not an adorable father, not a faithful husband and even, not a devoted Jew although as a father and a husband, he has never been willing to leave his family. In a conversation which goes on between Ahmad and Jack at the end of the novel, he reveals the reality of his life which partially reminds one of the reality of Wandering Jew's life:

A woman I was crazy about has ditched me, my job is a drag, I wake up every morning at four and can't get back to sleep. My wife-Jesus, it's too sad. She sees how unhappy I am and blames herself, for having gotten so ridiculously fat, and has gone on this crash diet that might kill her... I want to tell her, 'Beth, forget it, nothing's going to bring us back, when we were young.' ... The one child we had, his name is Mark, lives in Albuquerque and just wants to forget us (p. 303).

Jack, sleepless at nights, concerned with his death and willing to die, hating consumerism as well as obesity of his wife, and rejected by another woman and even his own son, seems not to be interested in the life he is living. He is in fact wandering in the depths of his loneliness, in a world he, like a Wandering Jew, wants it to be ended with a sweet 
death. But ironically, this world-weary man who laments the consumerism which has haunted people's daily lives turns out to be the savior of a Muslim who is isolated from the outside world, the world which in his (Ahmad's) view offers nothing but corruption. While Ahmad, a representative character of fundamentalists, recognizes the devotion to consumerism as a justification for his decision to carry out the terrorist act, Levy, himself an anti-consumerist and Updike's speaker in the novel, expresses his confusion about the appropriateness of this extremist motive by his attempt to prevent him from blowing up the tunnel.

The characters in the novel are situated in a microcosm which represents a macrocosm. Ahmad is an Arab-American who is more a representative of Muslim Arabs than a model of an American teenager. Also, Jack not only acts as an American but also reminds one of the values of the political Zionism due to his contrast with Ahmad. While Ahmad is drowning in the darkness of negligence symbolized by the darkness of the tunnel which is supposed to be the graveyard of the innocent American people, Jack like a prophet (his real name is Jacob, reminding one of Jacob, the Prophet), leads him to the light of consciousness symbolized by the light of the sun outside the tunnel; the consciousness of the fact that God is a creator not a destructor. This is the same so-called consciousness and light that Zionism claims to offer Palestinians.

Jack, also, by preventing Ahmad from blowing up the bomb, helps him to regain his freedom. Joining the Fundamentalist groups, the Muslim Arabs give up their own freedom and independence in favor of the group's beliefs and creeds. As such, Ahmad dedicates his mind and will to the extremist conceptions of the group and heads to fulfill his mission, though he is not willing to do that as a human being. The decision he makes at the end of the novel is in fact, his first decision made of his free will. Once more, it is Jack who helps him to come back to his self-consciousness, to the freedom which was crushed by the heaviness of the group's dictatorship. Indeed, it is Jack who 'frees' him from the bonds of captivity and wakes him up to the reality of liberty; the liberty which Zionism claims it bring to Palestinians. But, ironically, Ahmad's freedom from the bonds of extremism leads to another captivity; this time, he lets himself be colonized by the Jewish character, Jack, just in the same way that Zionists colonize the Orientals in the name of freedom.

The contrast between Jack's way of life and Ahmad's not only questions the terrorists' motives and reminds one of Zionism's so-called values, but also helps the readers to penetrate into Jack's depth of personality as a Jew. Updike, as a Neo-Orientalist, develops his Jew and Muslim characters, Jack, Ahmad and Shaikh Rashid, to delineate and highlight the Neo-Orientalist binary oppositions of the West/East and we/them in the novel. According to such binaries, Jack and his accompanying traits suggests the active, democratic, modern and civilized West and Shaikh Rashid and his pupil, Ahmad represent the passive, anti-democratic, and anti-modern East.

To accentuate the 'truth' of these binaries, Updike portrays the potential of Jack and Shaikh Rashid to act as a father figure in the novel. On the one hand, there is Shaikh Rashid, Ahmad's teacher since his childhood, who is supposed to act as a father, protector and leader for Ahmad due to their affinity in religion, beliefs and the hours they have spent together for nine years. On the other hand, there is Jack, the school's counselor, who though knows Ahmad for a short time, cares for his future. The characters' true natures come to be revealed at the end of the novel when Ahmad, religiously brainwashed by Shaikh Rashid, heads to fulfill his suicidal mission in the name of Allah and with the hope of entering the Paradise as a martyr. Here, this is Jack who insists on dying with Ahmad: "I don't think I'll get out. We're in this together, son" (p. 296), while Shaikh Rashid had left him alone to do his mission by himself the night before. Furthermore, this is Jack again who proves to be the only reliable and honest character while the Muslim ones betray Ahmad: Shaikh Rashid by slaving him to his own extremist beliefs first and putting him in jeopardy by persuading him to undertake that heroic mission later and Charlie, the son of an immigrant Lebanese boss of the Furnishing company Ahmad works for, who as a CIA undercover, "was using you (Ahmad) to flush out the others" (p. 292). Therefore, though Ahmad is manipulated by the Muslim characters around him, he receives genuine love and protection of the Jewish character of the novel, Jack Levy.

In addition to establishing the binaries of 'the self'/'the other', Updike tries to construct the identity of 'the self' Jack Levy-- through the construction of 'the Other'-Ahmad-because as Alaswad (2000) states, "Construction of the ethnic Other is closely connected to the construction of the Self-identity" (p. 42). In contrast to the early scholars on colonialism, Aime Cesaire, for instance, who denied any kind of interaction between colonizer and colonized except the relations of domination and submission, Homi Bhabha believes that the colonizer's identity has no 'origin' in himself and is not a fixed identity, but is differential. As in Lacan, identity is constructed in interaction with 'others' and with 'the other' (Bertens, 2001). As such, Jack attempts to befriend Ahmad in order to stabilize his own identity. Although his initial efforts are unsuccessful, he ultimately succeeds in knowing Ahmad's internal thoughts, religious beliefs and complex character through deeper investigations, even sleeping with Ahmad's mother. This search for the self establishes his dominance as a modern, democratic, secular Westerner so much so that he manages to dictate his power to Ahmad at the end of the novel when he miraculously saves Ahmad from the trap which was set for him and supports him with the answers Ahmad was supposed to give to the police's questions.

Although Jack Levy seems to be a passive character politically, he is the speaker of the Western vantage point regarding the issues of colonialism, Israel and democracy. When discussing over the job Ahmad is going to select, Jack recommends him to join the Army. Here, as a Westerner, he sides with the so-called values of American colonialism in Iraq: 
"If you have no job prospects think about the army... If you have any Arabic, they'd love you."Ahmad's expression stiffens. "The army would send me to fight my brothers." "Or to fight for your brothers, it could be. Not all Iraqis are insurgents, you know. Most aren't. They just want to get on with business. Civilization started there. They had an upand- coming little country, until Saddam." (p. 40-1)

Definitely, such an American value - civilizing 'the others' - is one of the so-called values Israel claims to endow the Palestinians with because Israeli colonialism is inspired by American colonialism and consequently, Jack, as a Jew, advocates it. Parenthetically, it is a wonder indeed how a writer of Updike's stature, supposedly an intelligent one, could so grossly oversimplify and distort the brute realities of the occupation of Iraq, could so brazen facedly be a mouthpiece for the American government. Updike's last novel was a surprise indeed!

As Batchelor (2009) points out, "the one character in Terrorist who is thought to be somewhat level-headed from a political standpoint cannot get past his own racist sentiments and the aftermath of 9/11" (p. 70). In the graduation party, Jack's mind is abruptly led to remember the pains, genocide and violence the European Jews had endured during the World War II: "Europe's Jews dressing up in their clothes to be marched off to the deaths camps" (Terrorist, p. 111). Later, when a Muslim imam begins his lecture in the party, he is reminded of Israel again. Then, his good will toward the imam is replaced with an image which connotes suffocation as if Islam and Muslims have been responsible for what had happened to synagogues:

When Levy thinks of embattled Israel and of Europe's pathetically few remaining synagogues needing to be guarded by police day and night, his initial good will toward the imam dissolves: the man in his white garb sticks like a bone in the throat of the occasion (p. 112).

Acting as a prophet at the end of the novel, Jack brings his mission to perfection by prophesying Ahmad's and ArabAmericans' future. Having succeeded in changing Ahmad's decision, Jack recommends him to be a lawyer: "I know this may sound premature, but I wasn't kidding about you making a good lawyer. You're cool under pressure. You talk well" (p. 309). Further, he continues to foresee the future of Islamic fundamentalism and Muslims, implying the NeoOrientalist idea that Muslims or as Jack prefers to call them Arab-Americans, are criminals, the belief that is haunting the minds and turning into a fact: "In the years to come, Arab-Americans are going to need plenty of lawyers" (p. 309).

\section{Conclusion:}

Regarding the deep influence that September 11, 20001 exerted over Americans, many serious and popular writers put their pen to write about both the mental consequences of those events from the vantage point of the survivors and terrorists' motives for committing the attacks. Due to Zionism's authority over American cultural discourse, many of the post-9/11 novelists focused on portraying Jewish characters which were in one way or another associated with political Zionism. John Updike's Terrorist is one of those novels which characterizes its Jewish character, Jack Levy, to represent both American and Zionist colonial values. Jack, acting as a prophet, saves Ahmad, the Arab-American character from the darkness of his religious unconsciousness and leads him to regain his lost freedom and in this way consolidates the so-called claims of his colonizer coreligionists for bringing freedom, civilization and democracy to the land of Palestine.

\section{REFERENCES}

[1] Alaswad, Saleh. (2000). "Hollywood Shoots the Arabs: The Construction of the Arab in American Culture." Ph.D. Dissertation, Temple University.

[2] Anidjar, Gil. (2003). The Jew, The Arab: A History of the Enemy. California: Standford University Press.

[3] Batchelor, Bob. (2009). "Running Toward the Apocalypse: John Updike's New America." Ph.D. Dissertation, University of South Florida.

[4] Bertens, Hans. (2001). The Basics, Literary Theory. New York: Routledge.

[5] Corrigan, Edward C. (2009). "Is Anti-Zionism Anti- Semitism? Jewish Critics Speak." Middle East Policy 2, 146-159.

[6] Goldschmidt, Arthur. (2006). A Concise History of the Middle East. Colorado: Westview Press.

[7] Jansen, G. H. (1971). Zionism, Israel and Asian Nationalism. Beirut: Institute for Palestine Studies.

[8] Kidd, Thomas S. (2010). "American Christians and Islam: Evangelical Culture and Muslims From the Colonial Period to the Age of Terrorism.” Insight Turkey 3, 255-6.

[9] Qumsiyeb, Mazin. (1978). “The Next 60 Years for Palestine.” Palestine- Israel Journal 3. 2008: 181-6.

[10] Said, Edward W. Orientalism. New York: Random House, Inc.

[11] Said, Edward. (1997). "Zionism From The Standpoint of its Victims.” Dangerous Liaisons: Gender, Nation, and Postcolonial Perspectives. Ed. McClintock, Anne, AAmir Mufti, Ella Shohat.USA: University of Minnesota Press.

[12] Schulzinger, Robert D. (2006). A Companion to American Foreign Relations. Oxford: Blackwell.

[13] Suver, Stacey A. (2008). "Exploding Narratives: The Literature of Terrorism in Contemporary America." M.A. Dissertation, Florida State University.

[14] Updike, John.(2006). Terrorist. New York: Penguin Group.

Maryam Salehnia. Born in Isfahan, Iran, 1985. B.A. degree in English Literature, from Isfahan University, Isfahan, Iran, in 2007. M.A. degree in English Literature, from Isfahan University, Isfahan, Iran, in 2011.

Now she is working as an English teacher in some private language teaching institutions in Iran. 